\title{
Analysis of the Effect of Return on Equity (Roe) and Debt to Equity Ratio (Der) On Stock Price on Cement Industry Listed In Indonesia Stock Exchange (Idx) In the Year of 2011-2015
}

\author{
Karnawi Kamar \\ Lecturer of STIE Insan Pembangunan
}

\begin{abstract}
The purpose of this research is to determine the effect simultaneously and partially variable of financial factors consisting of Return on Equity (ROE) and Debt to Equity Ratio (DER) on stock price. Population in this research is cement industry listed in Indonesia Stock Exchange totaling 3 cement companies. The method of data collection used is documentation method, while the method of analysis used is Ordinary Least Square (OLS) method with linear regression model facilitated by SPSS 23. The results shows that Return on Equity (ROE) has significant effect on the stock price, and Debt to Equity Ratio (DER) has effect but not significant on stock price. Through this research it is suggested that the investors in implementing the investment not only consider financial factor, but also pay attention to other factor that is not raised in this study, such as politic, economic and other in order to the investment decision can benefit the investors.
\end{abstract}

Keywords: Stock price, Return on Equity (ROE) and Debt to Equity Ratio (DER).

\section{A. Background}

\section{Introduction}

Accounting information used in the assessment process of company performance is financial ratios within a certain period. Financial ratio is the number obtained from the comparison of financial statement post with other posts that have relevant relationship. From the point of view of potential investor, to assess the company's future is to look at the extent to which the growth of the company's profitability. Whereas the indicator that is often used is Return on Equity (ROE), which illustrates the extent to which the company's ability to generate profit that can be obtained by shareholders. The high of ROE reflects that the company managed to generate a profit from its own capital. The increase of the value of ROE will increase the value of selling the company, which would certainly impact on stock price.

Other financial ratio often used is Debt to Equity Ratio (DER). DER is the comparison between debt and capital. The ratio can provide information about capital structure of a company. According to Law No. 40 of 2007 on limited liability company (UUPT), limited liability company consists of basic capital, issued capital and paid-up capital actualized in a set of stocks.

Cement industry listed in Indonesia Stock Exchange (IDX) is an industry with excellent prospect in the future and being able to grow today. The development of industry has a lot to give employment opportunities to job seekers in Indonesia and be able to show the progress in financial aspect and other aspects.

TABLE 1.1. Company Name, ROE, DER and stock price of year 2014 and 2015

\begin{tabular}{|l|l|l|l|l|}
\hline Company Name & Year & ROE & DER & Stock price \\
\hline PT. Indocement Tunggal Prakasa Tbk & 2014 & $21,80 \%$ & $0,50 \%$ & 25.000 \\
\hline & 2015 & $17,60 \%$ & $0,50 \%$ & 22.325 \\
\hline PT. Holcim Indonesia Tbk & 2014 & $8,00 \%$ & $63,00 \%$ & 2.185 \\
\hline & 2015 & $2,00 \%$ & $71,00 \%$ & 995 \\
\hline PT. Semen Indonesia Tbk & 2014 & $23,20 \%$ & $13,50 \%$ & 16.200 \\
\hline & 2015 & $17,10 \%$ & $12,70 \%$ & 11.400 \\
\hline
\end{tabular}

Source : www.idx.co.id: Annual Financial Report of IDX at 2014 and 2015

In Table 1.1 it is explained that PT. Indocement Tbk. decreased in ROE namely from $21,8 \%$ to $17,6 \%$ and DER of $0,5 \%$ is unchanged and stock price decreases from 25.000 per sheet of stock to 22.325 per sheet. Then in PT. Holcim Indonesia Tbk. is too, ROE decreases from $8 \%$ to $2 \%$ and the stock price decrease from 2.185 per sheet of stock to 995 per stock, but that DER increases from $63 \%$ to $71 \%$.

\section{B. Problem Formulation}

Based on the background of problems described above, problem formulations in this research are:

1. How is the effect of Return on Equity (ROE) and Debt to Equity Ratio (DER) simultaneously on stock price in cement industry listed in Indonesia Stock Exchange (IDX) in the year of 2011-2015? 
2. How is the effect of Return on Equity (ROE) on stock price in cement industry listed in Indonesia Stock Exchange (IDX) in the year of 2011-2015?

3. How is the effect of Debt to Equity Ratio (DER) on stock price in cement industry listed in Indonesia Stock Exchange (IDX) in the year of 2011-2015?

\section{Research Purpose}

In accordance with the formulation of problems that have been explained, the purpose of this research are:

1. Analyzing and determining the effect of return on equity (ROE) and Debt to Equity Ratio (DER) simultaneously on the stock price in cement industry listed in Indonesia Stock Exchange (IDX) in the year of 2011-2015.

2. Analyzing and determining the effect of Return on Equity (ROE) on stock prices in cement industry listed in Indonesia Stock Exchange (IDX) in the year of 2011-2015.

3. Analyzing and determining the effect of Debt to Equity Ratio (DER) on stock prices in cement industry listed in Indonesia Stock Exchange (IDX) in the year of 2011-2015.

\section{A. Financial Ratio Analysis}

\section{Theoretical Basis}

One of techniques for financial statements analysis is financial ratio analysis technique. Financial ratio according to Horne in Kasmir (2012:104), is an index that linking two accounting numbers and is obtained by dividing one number by another number. Thus, financial ratio is an activity comparing the numbers contained in the financial statements by dividing one number by another number. Comparison can be made between one component with component in one financial statement or between component that exists between the financial statements.

The result of this financial ratio is used to assess the performance of management in a period whether achieve the target that has been set or not, and can assess the ability of management to empower the company resource effectively.

Financial ratio analysis has benefit for company, according to Fahmi, Irham (2013: 109), namely:

1. Financial ratio analysis is very useful to be used as a tool to assess the performance and achievement of company.

2. Financial ratio analysis is very useful for the management as a reference for planning.

3. Financial ratio analysis can be used as a tool to evaluate the condition of a company from financial perspective.

4. Financial ratio analysis is also useful for creditors which it can be used to estimate the potential risks to be faced linked with the guarantee of continuity of the interest payment and repayment of principal guarantee.

5. Financial ratio analysis can be served as an assessment of stakeholder organization party.

Financial ratio used can be selected in several ratio groups, namely (Wahyudiono, 2014:74):

\section{Leverage Ratio (Solvency)}

Leverage ratio aims to measure how far the company uses debt. This ratio is often used for another term, namely the solvency ratio. This ratio measures the company's ability to meet its financial obligation.

\section{Liquidity Ratio}

This ratio is used to measure the company's ability to meet short-term obligation. The liquidity ratio consists of several types, including the ratio of net working capital with total assets, current ratio and quick or acid test ratio.

\section{Profitability Ratio}

Profitability ratio is also called the efficiency ratio. This ratio is used to measure the efficiency of the use of corporate asset. In addition, it is used to associate with successful sales created. Profitability ratio is divided into four ratios, namely Basic Earnings Power (BEP) or Economic Profitability, Return on Equity (ROE), Return on Investment (ROI), or Return on Assets (ROA), and Profit Margin.

\section{Activity Ratio}

This ratio measures how the effectiveness of company in using the resources of fund. The activity ratio is divided into three ratios, namely Asset Turnover, Inventory Turnover, and Receivable Turnover.

\section{Market Value Ratio}

To be able to calculate the ratio of market value, we should be able to acquire data coming from internal company financial report and data from capital market. The ratio of market value which is often used in financial statement analysis is Price Earning Ratio (PER) and Market to Book Value Ratio. 


\section{B. Return on Equity (ROE)}

According to Sugiono \& Untung (2016:66), profitability ratio is ratio intended to measure the effectiveness of management that is reflected in return for the investment result through the company's activities or in other words, measuring the company's overall performance and efficiency in the management of liabilities and capital.

Meanwhile, according to Kamaludin \& Indriyani (2012: 45), the profitability ratio shows the description about the effectiveness level of company management in generating profit. This ratio as a measure of whether the owner or shareholder can obtain a reasonable rate of return on their investment.

Return on Equity (ROE) is included in the profitability ratio. According to Prastowo, Dwi (2015:82), one of the main reasons operate the company is to generate profit that will be beneficial for shareholders. The success Measures of achievement of this reason is the number of ROE.

Horngren \& Harrison (2007:174) state that the return ratio on equity shows the relationship between net profit to equity of ordinary shareholder, how much the profit is earned on each $\$ 1$ invested by ordinary shareholder. ROE can be searched using the following formula:

\section{ROE $=$ Net Profit of Total Equity $x 100 \%$}

ROE is very beneficial both for shareholders and for prospective shareholders and also for management because the ratio is a measure or an important indicator of shareholders value cration, meaning, the higher the ratio, the higher the value of the company, it is certainly an attraction for investor to invest in the company.

\section{Debt to Equity Ratio (DER)}

Debt to Equity Ratio (DER) is one of the solvency ratio. According to Kashmir (2012:157), DER is a ratio used to assess the debt to equity by comparing the entire debt, including current liabilities with the overall of equity.

Regarding Debt to Equity Ratio, Joel G. Siegel and Jae K. Shim in Fahmi, Irham (2013:128) defines as a measure used in analyzing financial statement to show the amount of collateral available to creditor.

According to Harjito \& Martono (2014: 59) state that ratio of total debt to own capital is the comparison of total debt had by the company's own capital (equity). The formula to find the debt to equity ratio can be used the ratio between total debt with total equity as follows:

Debt to Equity Ratio = Total Debt to Equity cash flow.

DER for every company is different, depending on the characteristics of business and the diversity of

\section{Stock Price}

Capital market according to Harjito \& Martono (2014: 383) is a market in which funds are long-term both for debt and equity capital traded. Capital market according to Nidar, Sulaeman (2016:11) is the organized financial system overall, including commercial banks and all intermediaries in the financial field as well as long term securities.

Meanwhile, according to Widoatmodjo (2012:150), capital market can be said to be an abstract market, which traded is long-term funds, namely the attachment funds in an investment of more than one year.

Sartono, Agus (2012:21), states that stock market is a place of transaction of long-term or long-term financial assets or long-term financial assets ". Type of securities traded in capital markets have a maturity of more than one year. Capital market allows the need fulfillment of long-term funds for long-term investment in the form of buildings, equipment and other production facilities.

The understanding of stock market according to Law No. 8 of 1995, is the activity related to public offering and trade of stock, issuance stock of public company, as well as institution and profession in the field of stock. Capital Market is also better known by name the stock market (the stock market), because there is traded more stocks than bonds. On the stock market the value of stok is determined in other words that this place is very determining the value of company, such as the purpose of financial management.

\section{E. Theoretical Framework}

The relationship between the independent variables on the dependent variable either simultaneously or partially can be seen in figure below:

Figure 2.1. Theoretical framework:

Based on the figure above, it is explained that the independent variables namely Return On Equity (ROE) and Debt to Equity Ratio (DER) have simultaneously effect on dependent variable that is the stock price. 
Then partially independent variables of ROE $\left(\mathrm{X}_{1}\right)$ has effect on stock price $(\mathrm{Y})$, as well as DER $\left(\mathrm{X}_{2}\right)$ partially has effect on stock price (Y).

\section{F. Hypothesis}

According to Sugiyono (2012:64), stating that the "hypothesis or hypothesis is a temporary answer to the formulation of research problem, in which the formulation of research problem has been expressed in a question form". Hypothesis in this research are:

a. Return on Equity (ROE) and Debt to Equity Ratio (DER), have simultaneously effect on stock price in cement industry listed in Indonesia Stock Exchange (IDX) in the year of 2011-2015.

b. Return on Equity (ROE) has positive effect on stock price in cement industry listed in Indonesia Stock Exchange (IDX) in the year of 2011-2015.

c. Debt to Equity Ratio (DER) has positive effect on stock price in the cement industry listed in Indonesia Stock Exchange (IDX) in the year of 2011-2015.

\section{Research Methodology}

This research is included a quantitative research with emphasizing on the design of associative research, by examining the effect of Return on Equity (ROE) and Debt to Equity ratio (DER) as independent variable on stock price in cement industry listed in Indonesia Stock Exchange (IDX) as dependent variable. Data used in this research is data from cement industry that go public listed on Indonesia Stock Exchange (IDX), 2008 to 2015. Selection of IDX as a place to research, because the author considers that IDX as a place to obtain the necessary data, namely a report financial and stock price.

Variable in this research are: dependent variable $(\mathrm{Y})$ in this research is stock price. Stock price used is closing price (closing price), that is final price of buying and selling on stock exchange per $31^{\text {th }}$ December 2011 to 2015. Independent variables (independent variables), there are two (2): Return on Equity (ROE) / $\mathrm{X}_{1}$ and Debt to Equity Ratio (DER) / $\mathrm{X}_{2}$.

Technique of sample selection in this research uses technique of saturation sampling (census), namely the selection of samples by using all members of population as a sample. There are 3 cement companies listed on Indonesia Stock Exchange as the population and they are as sample in this research. All three cement companies are:

TABLE 3.1. List of Cement Companies Listed on Indonesia Stock Exchange

\begin{tabular}{|l|l|l|}
\hline No & \multicolumn{1}{|c|}{ Company Name } & \multicolumn{1}{c|}{ Company Code } \\
\hline 1 & PT. Indocement Tunggal Prakasa Tbk & INTP \\
\hline 2 & PT. Holcim Indonesia Tbk & SMCB \\
\hline 3 & PT. Semen Indonesia Tbk & SMGR \\
\hline
\end{tabular}

Source : www.idx.co.id

Data collection method used in this research is documentation method, that is by studying the company's records and documents in order to obtain the necessary data. This method is used to obtain data about the company's financial statements in order to obtain information about Return on Equtity (ROE), Debt to Equity Ratio (DER) and stock price.

This research uses data analysis method conducted in several steps, namely descriptive analysis, classical assumption test, correlation analysis, regression and hypothesis testing. To interpret the data obtained in this research, the author is assisted by using SPSS software application.

\section{A. Descriptive Analysis}

\section{Analysis and Discussion}

This research uses two independent variables and one dependent vaiabel. The independent variables in this research are Return On Equity (ROE) and Debt to Equity Ratio (DER), while the dependent variable is stock price.

\begin{tabular}{|c|c|c|c|c|c|c|c|}
\hline \multirow{3}{*}{$\begin{array}{l}\text { Descriptiv } \\
\text { e Statistics }\end{array}$} & & & & & & & \\
\hline & $\mathrm{N}$ & Range & Minimum & Maximum & Sum & Mean & \\
\hline & Statistic & Statistic & Statistic & Statistic & Statistic & Statistic & Std. Error \\
\hline ROE & 15 & 26 & 2 & 28 & 290 & 19,34 & 2,049 \\
\hline $\begin{array}{l}\text { Valid } \mathrm{N} \\
\text { (listwise) }\end{array}$ & 15 & & & & & & \\
\hline \multirow[t]{2}{*}{$\begin{array}{l}\text { Descriptiv } \\
\text { e Statistics } \\
\end{array}$} & & & & & & & \\
\hline & Std. & Variance & Skewness & Kurtosis & & & \\
\hline
\end{tabular}




\begin{tabular}{|l|l|l|l|l|l|l|}
\hline & Deviation & & & & \multicolumn{2}{|c|}{} \\
\cline { 2 - 6 } & Statistic & Statistic & Statistic & Std. Error & Statistic & Std. Error \\
\hline ROE & 7,936 & 62,988 &,- 827 &, 580 &,- 150 & 1,121 \\
\hline $\begin{array}{l}\text { Valid N } \\
\text { (listwise) }\end{array}$ & & & & & & \\
\hline
\end{tabular}

Source: it was processed from secodary data, 2016

Display result of SPSS output gives Skewness value and kurtosis respectively -,827 and -,150 so it can be concluded that ROE is normal distribution. Value of range is the difference between minimum and maximum value that is equal to 26 and value of sum is the sum of 15 ROE that is equal to 290.

The result of descriptive statistic of Return On Equity (ROE) in the period 2011-2015, is shown in the following table:

TABLE 4.2. The results of descriptive statistic of Debt to Equity Ratio (DER)

\begin{tabular}{|c|c|c|c|c|c|c|c|}
\hline $\begin{array}{l}\text { Descriptive } \\
\text { Statistics }\end{array}$ & & & & & & & \\
\hline & $\mathrm{N}$ & Range & Minimum & Maximum & Sum & Mean & \\
\hline & Statistic & Statistic & Statistic & Statistic & Statistic & Statistic & Std. Error \\
\hline DER & 15 & 99 & 11 & 110 & 675 & 44,99 & 8,099 \\
\hline Valid N (listwise) & 15 & & & & & & \\
\hline \multicolumn{8}{|l|}{$\begin{array}{l}\text { Descriptive } \\
\text { Statistics }\end{array}$} \\
\hline & $\begin{array}{l}\text { Std. } \\
\text { Deviation }\end{array}$ & $\begin{array}{l}\text { Varianc } \\
\mathrm{e}\end{array}$ & Skewness & Kurtosis & & & \\
\hline & Statistic & Statistic & Statistic & Std. Error & Statistic & Std. Error & \\
\hline DER & 31,366 & 983,814 &, 515 &, 580 &,- 803 & 1,121 & \\
\hline Valid N (listwise) & & & & & & & \\
\hline
\end{tabular}

Source: it was processed from secodary data, 2016

Kurtosis and skewness are a measure to see whether data are normally distributed or not. Skewness measures the skewness of data and kurtosis measures the top of distribution data. Normal distribution data has a value of kurtosis and skewness close to 0. Display results of SPSS output give value of kurtosis and skewness respectively 0,515 and,- 803 so it can be concluded that DER is normal distribution. The range value is the difference between minimum and maximum value that is equal to 99 and the sum value is the sum of 15 DER is equal to 675 .

The results of descriptive statistics of stock price in the period 2011-2015, are shown in the following table:

TABLE 4.3. The results of descriptive statistics of stock price

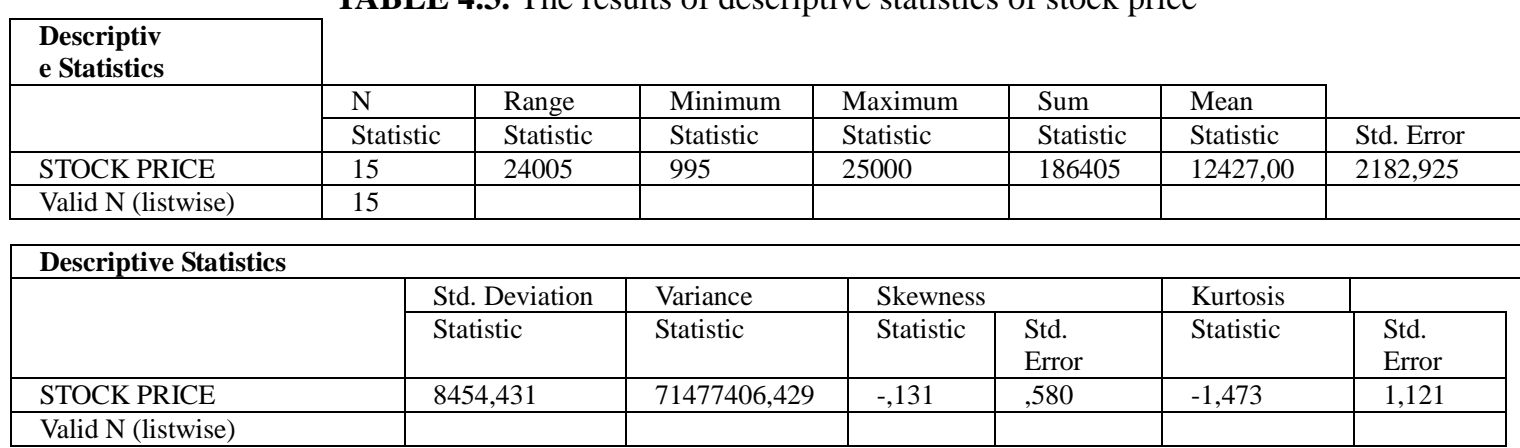

Source: it was processed from secondary data,2016

SPSS output shows the amount of data (N) are 15, from 15 of this data the smallest Stock Price is 995 and the largest stock price is 25.000 . The average of stock price is 12.427 with standard deviation of 8454,431 . Skewness measures the skewness of data and kurtosis measures the top of distribution data. Data of normal distribution has a skewness value close to 0. Display result of SPSS output gives skewness value of -,131 so it can be concluded that stock price is normally distributed. The range value is the difference between the minimum and maksimum amounted to 24.005 and the sum value is the sum of 15 stock price that is 186.405 .

\section{B. Classical Assumption Test}

Classical assumption test is a statistical requirements to be met by multiple linear regression analysis based Ordinary Least Square (OLS). Classical assumption test in this study are: 


\section{Normality Test}

Normality test aims to test whether the regression model, confounding variables or residuals have a normal distribution or not. Normality test in this research uses P-Plot.

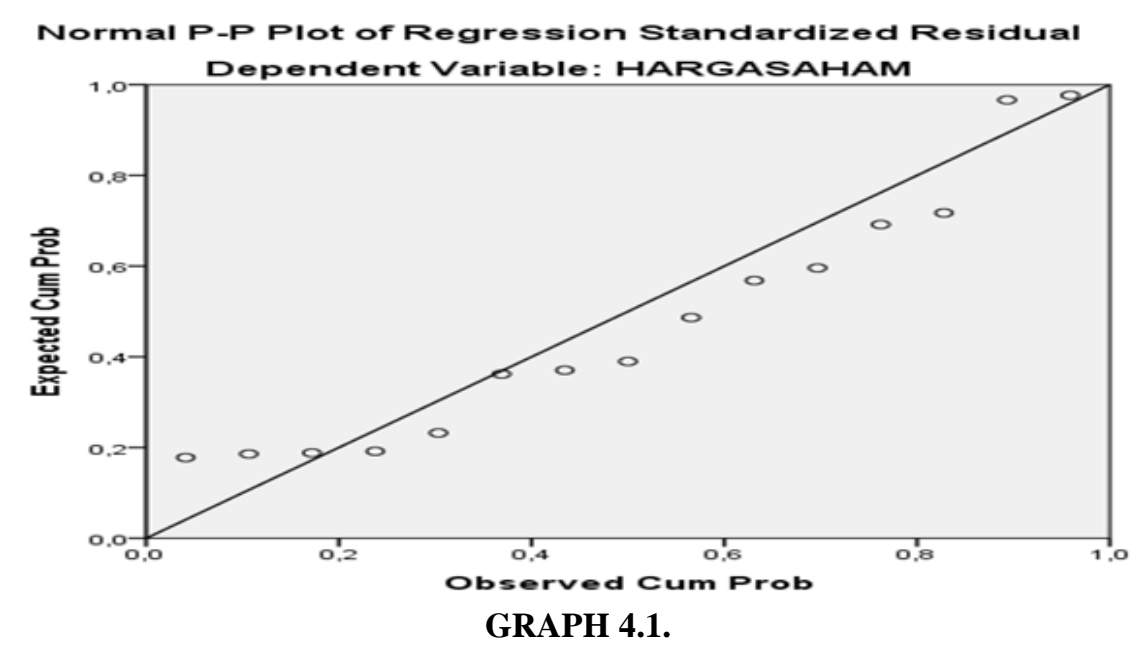

\section{Graph of P Plot}

Based on the graph of P-Plot it seems that dots follow and approach the diagonal line so it can be concluded that the regression model meets the assumption of normality.

\section{Multicollinearity Test}

Multicolinearity test is conducted to determine whether there is effect (multicollinearity) between independent variables and can be detected by calculating the correlation coefficient between independent variables.

TABLE 4.4. Results of Multicollinearity Test

\begin{tabular}{|l|l|l|l|}
\hline \multicolumn{2}{|l|}{ Coefficients $^{\mathbf{a}}$} \\
\hline \multirow{2}{*}{ Model } & Collinearity Statistics \\
\cline { 3 - 4 } & (Constant) & & VIF \\
\cline { 2 - 4 } & ROE &, 974 & 1,027 \\
\cline { 2 - 4 } & DER &, 974 & 1,027 \\
\hline
\end{tabular}

Source: processed from secondary data,2016

Based on the VIF result above obtained VIF value of $1,027<10$, it can be concluded that the model does not have indication of Multicolinearity.

\section{Heteroscedasticity Test}

This testing aims to test whether in regression model experiencing inequality variance of residual from one observation to another observation.

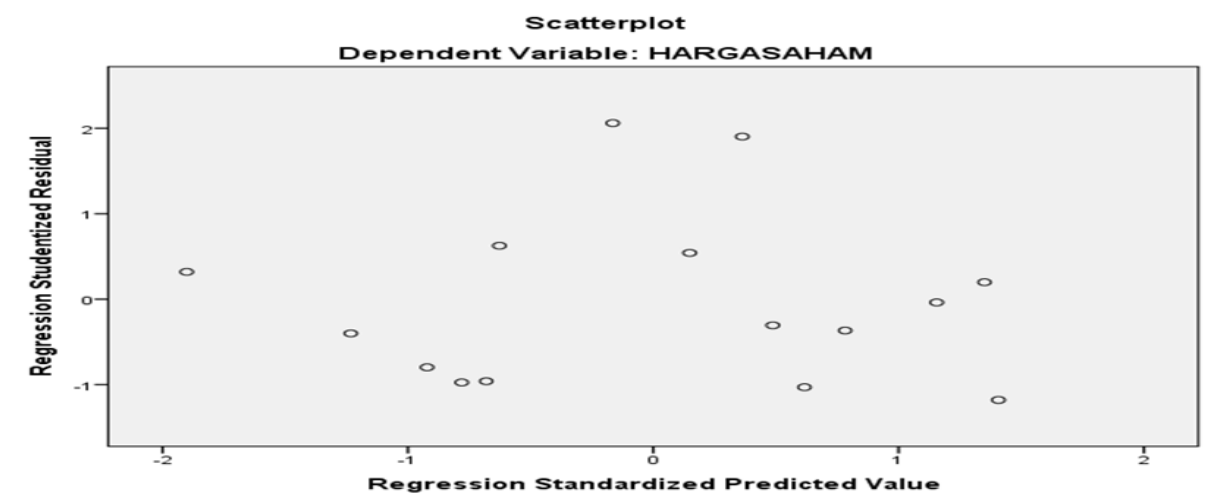

GRAPH 4.2. 


\section{Scatterplot graph}

Based on the graph above it can be seen that the dots do not form a clear pattern, and the dots spread above and below the number 0 on the $\mathrm{Y}$ axis. So it can be concluded that there is no problem of heteroscedasticity.

\section{Autocorrelation Test}

Autocorrelation test aims to determine whether the dependent variable on the year of observation is influenced by dependent variable before the year of observation.

TABLE 4.5. Result of autocorrelation test

\begin{tabular}{|l|l|l|l|l|l|}
\hline Model Summary $^{\mathbf{b}}$ & $\mathrm{R}$ & R Square & $\begin{array}{l}\text { Adjusted } \\
\text { Square }\end{array}$ & $\begin{array}{l}\text { Std. Error of the } \\
\text { Estimate }\end{array}$ & Durbin-Watson \\
\hline Model &, $795^{\text {a }}$ &, 632 &, 570 & 5542,501 & 1,250 \\
\hline 1 & &
\end{tabular}

Source: processed from secondary data, 2016

The value of DW by 1,250 , while according to the table of Durbin Watson with a number of independent variables $(\mathrm{k})=2$ and total $(\mathrm{n})=15$ then the value $\mathrm{dL}$ (lower limit) of 0,9455 . $\mathrm{d}$ value by $1,250>\mathrm{dL}$ by 0,9455 . Then, $4-\mathrm{dL}=3,0545>1,250$ so it can be concluded that the regression model doesn't contain autocorrelation.

\section{Regression Analysis}

1. Simple Linear Regression Analysis

This analysis to determine the direction of relationship between independent variables and dependent variable whether positive or negative, and to predict the value of dependent variable when the value of independent variable increase or decrease.

\section{a. Regression test of $\mathrm{X}_{1} \mathrm{Y}$}

TABLE 4.9. The result of Simple Linear Regression of $X_{1} Y$

\begin{tabular}{|l|l|l|l|l|l|l|}
\hline \multicolumn{2}{|l|}{ Coefficients $^{\mathbf{a}}$} & \multicolumn{2}{|l|}{ Unstandardized Coefficients } & \multicolumn{2}{l|}{$\begin{array}{l}\text { Standardized } \\
\text { Coefficients }\end{array}$} & Sig. \\
\cline { 3 - 7 } & Bodel & B & Std. Error & Beta & & \\
\hline \multirow{2}{*}{1} & (Constant) & $-3021,903$ & 4065,960 & &,- 743 &, 471 \\
\cline { 2 - 6 } & ROE & 798,861 & 195,449 &, 750 & 4,087 &, 001 \\
\hline
\end{tabular}

Source: Result was processed from secondary data, 2016

The relationship between ROE $\left(\mathrm{X}_{1}\right)$ with stock Price $(\mathrm{Y})$ has a constant value of $-3021,903$ which means that if the value of $\mathrm{ROE}=0$, then the value of stock price is 3021,903. Regression coefficient value of ROE is 798,861 , it means that every increase of $1 \%$ ROE, it will raise the stock price valued at 798,861 . Thus, simple linear regression equation can be written as follows:

Stock price $=-3021,903+798,861 \mathrm{ROE}+\mathrm{c}$

\section{b. Regression Test of $\mathrm{X}_{2} \mathrm{Y}$}

TABLE 4.10.Result of Simple Linear Regression of $\mathrm{X}_{2} \mathrm{Y}$

\begin{tabular}{|c|c|c|c|c|c|c|}
\hline \multicolumn{7}{|c|}{ Coefficients ${ }^{\mathrm{a}}$} \\
\hline \multirow{2}{*}{\multicolumn{2}{|c|}{ Model }} & \multicolumn{2}{|c|}{ Unstandardized Coefficients } & Standardized & $\mathrm{t}$ & Sig. \\
\hline & & $\mathrm{B}$ & Std. Error & Beta & & \\
\hline \multirow[t]{2}{*}{1} & (Constant) & 10745,399 & 4016,135 & & 2,676 & 019 \\
\hline & DER & 37,374 & 74,036 & ,139 & ,505 & ,622 \\
\hline
\end{tabular}

The relationship between DER $\left(\mathrm{X}_{2}\right)$ with Price $(\mathrm{Y})$ has a constant value of 10745,399, which means that if the value of DER $=0$, then the value of stock price of 10745,399. DER regression coefficient value of 37,374 , it means that every increase of $1 \%$ ROE, it will raise the stock price of $37,374 \%$. Thus, simple linear regression equation can be written as follows:

Stock price $=10745,399+37,374 \mathrm{DER}+\mathrm{c}$ 


\section{Analysis of Multiple Linear Regression Test}

Multiple linear regression is a dependent metric variable predicted by several independent metric variable. Multiple regressions is an extension of simple linear regression.

TABLE 4.11. Result of Multiple Linear Regression

\begin{tabular}{|l|l|l|l|l|l|l|}
\hline \multicolumn{2}{|l|}{ Coefficients $^{\text {a }}$} & \multicolumn{2}{l|}{ Unstandardized Coefficients } & $\begin{array}{l}\text { Standardized } \\
\text { Coefficients }\end{array}$ & $\mathrm{t}$ \\
\cline { 3 - 7 } \multicolumn{2}{|l|}{ Model } & B & Std. Error & Beta & & \\
\hline \multirow{2}{*}{1} & (Constant) & $-7141,963$ & 4754,159 & & $-1,502$ &, 159 \\
\cline { 2 - 7 } & ROE & 844,700 & 189,123 &, 793 & 4,466 &, 001 \\
\cline { 2 - 7 } & DER & 71,868 & 47,854 &, 267 & 1,502 &, 159 \\
\hline
\end{tabular}

Source: Result processed from secondary data, 2016

According to the table above, the equation of multiple linear regression can be written as follows: Stock price $=-7141,963+844,7 \mathrm{ROE}+71,868 \mathrm{DER}+\mathrm{c}$

Through the regression equation above it can be seen that the variable that gives significantly effect on stock prices is ROE (as seen from p-value on significance 0,001). ROE has a positive coefficient, which means if the value of regression coefficient of other variable is constant, then any increase in ROE by $1 \%$ will increase the stock price of $844,7 \%$. While DER also has a positive coefficient, which means, if the value of regression coefficient of other variable is constant, the then any increase in DER by $1 \%$ would lead to stock price increase of $71,868 \%$.

\section{Coefficient of Determination}

It indicates the percentage of the effect of all independent variables on dependent variable. The magnitude of determination coefficient from 0 to 1 .

\section{a. Determination coefficient of $\mathbf{X}_{1} \mathbf{X}_{2} \mathbf{Y}$}

TABLE 4.12. Result of determination coefficient of $X_{1} X_{2} Y$

\begin{tabular}{|l|l|l|l|l|}
\hline Model Summary $^{\mathbf{b}}$ & Adjusted R Square & Std. Error of the Estimate \\
\hline Model & $\mathrm{R}$ & $\mathrm{R}$ Square &, 570 & 5542,501 \\
\hline 1 &, $795^{\mathrm{a}}$ &, 632 &, 50 & \\
\hline
\end{tabular}

Source: Result processed from secondary data, 2016

Based on the calculation result above is obtained $\mathrm{R}$ Square of $63,2 \%$, meaning that approximately $63,2 \%$ of variation of independent variables of $\operatorname{ROE}\left(\mathrm{X}_{1}\right)$ and DER $\left(\mathrm{X}_{2}\right)$ can explain the variation of dependent variable of Stock Price (Y), while the remaining 36.8\% can explained by other factors such as EPS, ROA, political turmoil in the country, a different perception of each investor and others.

\section{b. Determination Coefficient of $X_{1} Y$}

TABLE 4.13. Result of determination coefficient of $X_{1} Y$

\begin{tabular}{|l|l|l|l|l|}
\hline Model Summary & R & R Square & Adjusted R Square & Std. Error of the Estimate \\
\hline Model &, $750^{\mathrm{a}}$ &, 562 &, 529 & 5803,973 \\
\hline 1 &
\end{tabular}

Source: Result processed from secondary data, 2016

Based on the calculation result above is obtained $\mathrm{R}$ square of $56,2 \%$, meaning that approximately $56,2 \%$ of variation of independent variables of ROE (X1) can explain the variation of dependent variable of Stock Price (Y), while the remaining $43,8 \%$ can be explained by other factors not included in the variables examined in this research.

\section{c. Determination Coefficient of $\mathrm{X}_{2} \mathrm{Y}$}

TABLE 4.14. Result of determination coefficient of $X_{2} Y$
\begin{tabular}{|l|l|l|l|l|}
\hline Model Summary & R & R Square & Adjusted R Square & Std. Error of the Estimate \\
\hline Model &, $139^{\mathrm{a}}$ &, 019 &,- 056 & 8688,827 \\
\hline 1 &
\end{tabular}

Source: Result processed from secondary data, 2016

Based on the calculation result above is obtained R-square of $1,9 \%$, meaning that about $1.9 \%$ of variation of independent variables of DER $\left(\mathrm{X}_{2}\right)$ can explain the variation of dependent variable of Stock Price 
(Y), while the remaining $98,1 \%$ can be explained by other factors not included in the variables examined in this research.

\section{Hypothesis Test}

Proving the hypotheses simultaneously and partially is used test tool as follows:

a. Simultaneous Test (Test F)

Simultaneous testing is used to see whether there is an effect of Return on Equity (ROE) and Debt to Equity Ratio (DER) on stock price. By comparing $\mathrm{F}_{\text {count }}$ with $\mathrm{F}_{\text {table. }}$

$\mathrm{F}_{\text {table }}=(\mathrm{a}: \mathrm{k}-1, \mathrm{n}-\mathrm{k}), \mathrm{a}=0,05,(3-1,15-3)$ then $(0,05: 2,12)$. As for the hypotheses used are:

1. $\mathrm{H}_{0}: \mathrm{b}_{1}=\mathrm{b}_{2}=0=$ there is no significant effect simultaneously between ROE and DER on stock price.

2. $\mathrm{H}_{1}: \mathrm{b}_{1}=\mathrm{b}_{2} \neq 0=\quad$ There is significant effect simultaneously between ROE and DER on stock price.

The decisions to reject or accept $\mathrm{H}_{0}$ are:

a) $\mathrm{H}_{0}$ is accepted and $\mathrm{H}_{1}$ is rejected, if $\mathrm{F}_{\text {count }} \leq \mathrm{F}_{\text {table }}$,

b) $\mathrm{H}_{0}$ is rejected and $\mathrm{H}_{1}$ is accepted, if $\mathrm{F}_{\text {count }} \geq \mathrm{F}_{\text {table }}$.

TABLE 4.15. Anova test (Simultaneous)

\begin{tabular}{|c|c|c|c|c|c|}
\hline \multicolumn{6}{|l|}{ ANOVA $^{a}$} \\
\hline Model & Sum of Squares & df & Mean Square & $\mathrm{F}$ & Sig. \\
\hline 1 Regression & 632051822,182 & 2 & 316025911,091 & 10,288 &, $002^{\mathrm{b}}$ \\
\hline Residual & 368631867,818 & 12 & 30719322,318 & & \\
\hline Total & 1000683690,000 & 14 & & & \\
\hline
\end{tabular}

Source: Result processed from secondary data, 2016

The result of calculation above that is $F_{\text {count }}=10,288$, while $F_{\text {table }}=3,89(a=0,05: 2: 12)$. From the comparison between $F_{\text {count }}$ and $F_{\text {table }}$, showed the value of $F_{\text {count }}>F_{\text {table }}$ then $\mathrm{H}_{0}$ is rejected and $\mathrm{H}_{1}$ is accepted,. in other words, variables of ROE and DER simultaneously have significant effect on stock price with a confidence level of $95 \%$. Based on ANOVA test or F-test, a significance level of 0,002 is less than 0,05, there is effect of Return on Equity (ROE) and Debt to Equity Ratio (DER) on the company's stock price. From F-test it can be concluded that the independent variables (ROE and DER) simultaneously have significant effect on dependent variable (stock price).

\section{b. Partial test (t test)}

Partial test is used to determine whether there is effect of Return on Equity (ROE) and Debt to Equity Ratio (DER) individually on stock price. Steps of determining t test, namely:

1. Determining Hypothesis

a.) $\mathrm{H}_{0}: \mathrm{b}_{1}=0=$ there is no significant effect between ROE on Stock Price of cement industry listed on Indonesia Stock Exchange.

b.) $\mathrm{H}_{2}: \mathrm{b}_{1} \neq 0=$ There is significant effect between ROE on stock Price of Cement industry listed on Indonesia Stock Exchange.

c.) $\mathrm{H}_{0}: \mathrm{b}_{1}=0=$ There is No significant effect between DER on Stock Price of cement industry listed on Indonesia Stock Exchange.

d.) $\mathrm{H}_{3}: \mathrm{b}_{1} \neq 0=$ There is significant effect between DER on stock Price of Cement industry listed on Indonesia Stock Exchange

2. Calculating the $t_{\text {count }}$ value uses SPSS 23 software.

3. Finding the critical value of $t_{\text {table }}$ by knowing the value of $\mathrm{df}$ (degree of freedom) i.e. (n-k) and determining the significant level, i.e. $\mathrm{a} / 2=5 \% / 2=0,025$. So $\mathrm{t}_{\text {table }}$ value is obtained by 2,17881 .

4. The decision to reject or accept $\mathrm{H}_{0}$, namely:

$\mathrm{H}_{0}$ is accepted and $\mathrm{H}_{\mathrm{a}}$ is rejected, if: $\mathrm{t}_{\text {count }} \leq \mathrm{t}_{\mathrm{tab}}$ or if sig. value $>0,05$

$\mathrm{H}_{0}$ is rejected and $\mathrm{H}_{\mathrm{a}}$ is accepted, if: $\mathrm{t}_{\text {count }}>\mathrm{t}_{\mathrm{tab}}$ or if sig. value $<0,05$

\section{a. Partial testing of ROE $\left(\mathrm{X}_{1}\right)$}

TABLE 4.16. Partial Hypothesis Test (t test) of Variable ROE on stock price

\begin{tabular}{|c|c|c|c|c|c|}
\hline \multicolumn{6}{|l|}{ Coefficients $^{\mathrm{a}}$} \\
\hline \multirow[t]{2}{*}{ Model } & \multicolumn{2}{|c|}{ Unstandardized Coefficients } & Standardized & \multirow[t]{2}{*}{$\mathrm{t}$} & \multirow[t]{2}{*}{ Sig. } \\
\hline & B & Std. Error & Beta & & \\
\hline \begin{tabular}{l|l}
1 & (Constant) \\
\end{tabular} & $-3021,903$ & 4065,960 & & $\begin{array}{l}-, 743 \\
\end{array}$ & ,471 \\
\hline ROE & 798,861 & 195,449 & ,750 & 4,087 & ,001 \\
\hline
\end{tabular}

Source: Result processed from secondary data, 2016 
Based on $t$ test results above, $t_{\text {count }}$ value of ROE of 4,087> $t_{\text {table }}$ value of 2,17881 with sig of $0,001<$ 0,005 , it can be concluded that $\mathrm{H}_{0}$ is accepted and $\mathrm{H}_{2}$ is rejected, which means there is significant effect between ROE (X1) with Stock Price (Y).

\section{b. Partial testing of DER $\left(\mathbf{X}_{2}\right)$}

TABLE 4.17.Partial Hypothesis Test (t test) of DER variable on stock price

\begin{tabular}{|c|c|c|c|c|c|}
\hline \multicolumn{6}{|l|}{ Coefficients $^{\mathrm{a}}$} \\
\hline \multirow[t]{2}{*}{ Model } & \multicolumn{2}{|c|}{ Unstandardized Coefficients } & Standardized & \multirow[t]{2}{*}{$\mathrm{t}$} & \multirow[t]{2}{*}{ Sig. } \\
\hline & $\mathrm{B}$ & Std. Error & Beta & & \\
\hline (Constant) & 10745,399 & 4016,135 & & 2,676 & 019 \\
\hline DER & 37,374 & 74,036 & ,139 & ,505 & ,622 \\
\hline
\end{tabular}

Source: Result processed from secondary data, 2016

Based on $t$ test results above, $t_{\text {count }}$ value of DER of $0,505<t_{\text {table }}$ value of 2,17881 with sig value of $0,622>0,005$, it can be concluded that $\mathrm{H}_{0}$ is rejected and $\mathrm{H}_{2}$ is accepted, which means there is no significant effect between DER (X2) with stock price (Y).

\section{Solving Problem}

Setelah melakukan perhitungan dan analisa, maka hasil yang diperoleh dari pengujian tersebut digunakan untuk menjawab beberapa perumusan masalah di awal, yaitu:

After doing the calculation and analysis, the results obtained from these tests are used to answer the problem formulation in the beginning, namely:

1. How is the effect of Return on Equity (ROE) and Debt to Equity Ratio (DER) simultaneously on stock price in cement industry listed in Indonesia Stock Exchange (IDX) in the year of 2011-2015?

Based on the calculation of determination coefficient, it shows that simultaneously Return on Equity (ROE) and Debt to Equity Ratio (DER) have effect amounted to $63.2 \%$ on stock price, it is also proved that by the results of calculation in hypothesis test (F Test) simultaneously. Results obtained from the F-test calculation is $F_{\text {count }}=10,288$ while $F_{\text {table }}=3,89(\mathrm{a}=0,05: 2: 12)$. From the comparison between $F_{\text {count }}$ and $F_{\text {table }}$, shows that the value of $\mathrm{F}_{\text {count }}>\mathrm{F}_{\text {table }}$ then $\mathrm{H}_{0}$ is rejected and $\mathrm{H}_{1}$ is accepted,. in other words, variables of ROE and DER simultaneously have significant effect on stock price in cement industry listed on IDX. Thus regression model resulted, namely:

Stock price $=-7141,963+844,7 \mathrm{ROE}+71,868 \mathrm{DER}+\mathrm{c}$ can be used to predict the stock price of cement industry when DER and ROE have increased or decreased.

2. How is the effect of Return on Equity (ROE) on stock price in cement industry listed in Indonesia Stock Exchange (IDX) in the year of 2011-2015?

Based on the calculation of determination coefficient, it shows that Return on Equity (ROE) has effect amounted to $56,2 \%$ on stock price of cement industry, it is also proved by the calculation results in a partial hypothesis test (t-test). Results obtained from the t-test calculation is $\mathrm{t}_{\text {count }} \mathrm{ROE}$ amounted to 4,087 > 2,17881 with sig value of $0,001<0,005$, it can be concluded that $\mathrm{H}_{0}$ is accepted and $\mathrm{H}_{2}$ is rejected, which means there is significant effect between $\operatorname{ROE}\left(\mathrm{X}_{1}\right)$ with stock price $(\mathrm{Y})$. Thus the regression model resulted, namely:

Stock Price $=-3021,903+798,861 \mathrm{ROE}+\mathrm{c}$ can be used to predict the stock price of cement industry when ROE has increased or decreased.

3. How is the effect of Debt to Equity Ratio (DER) on stock price in cement industry listed in Indonesia Stock Exchange (IDX) in the year of 2011-2015?

Based on the calculation of determination coefficient, it shows that Debt to Equity Ratio (DER) only has the effect amounted to $1.9 \%$ on stock price of cement industry, it is also proved by the calculation results in a partial hypothesis test (t-test). Results obtained from t-test calculation is $t_{\text {count }}$ DER of $0,505<t_{\text {table }}$ value of 2,17881 with sig value of $0,622>0,005$, it can be concluded that the $\mathrm{H}_{0}$ is rejected and $\mathrm{H}_{2}$ is accepted, which means there is no significant effect between DER $\left(\mathrm{X}_{2}\right)$ with Stock Price $(\mathrm{Y})$. Thus the regression model resulted, namely:

Stock Price $=10745,399+37,374$ DER $+\mathrm{c}$ can not be used to predict the stock price of cement industry when DER has increased or decreased.

\section{Conclusion}

This research is conducted to analyze the effect of Return on Equity (ROE) and Debt to Equity Ratio (DER) on stock price in cement industry listed in Indonesia Stock Exchange (IDX) from 2011 until 2015. Based on the results of research and discussion analysis has been done, it can be concluded as follows:

a. Variable of Return on Equity (ROE) and Debt to Equity Ratio (DER) simultaneously have significant effect on stock price of cement industry listed in Indonesia Stock Exchange (IDX) from 2011 until 2015. 
b. Partially, Return on Equity (ROE) has positive and significant effect on stock price of cement industry listed in Indonesia Stock Exchange (IDX) from 2011 until 2015.

c. Partially, Debt to Equity Ratio (DER) has positive effect and not significant on stock price of cement industry listed in Indonesia Stock Exchange (IDX) from 2011 until 2015.

d. The financial ratios used in this research is still less so it can not represent the financial ratios that can analyze the condition of company in relation to predicting stock price.

Based on the research results and conclusions that have been stated above, the researcher propose suggestions as follows:

a. For investors, before they invest their capital in a company, they have to consider the important information about the company.

b. Use of the stock price data in this study is per December 31, it is expected in future research using daily stock price data, because stock prices change every day.

c. Management of companies in cement industry should pay attention to the level of company solvency, because the aspect has a negative effect on stock price, which is expected to improve the company's value.

d. This research has a limited number of financial ratios slightly, then for further research it is expected to use financial ratios to more.

\section{References}

[1]. Fahmi, Irham. (2013). Pengantar Manajemen Keuangan. Bandung: Alfabeta

[2]. Harjito dan Martono. (2014). Manajemen Keuangan Edisi ke-2. Yogyakarta: Ekonisia

[3]. Harmono (2014). Manajemen Keuangan. Jakarta : Bumi Aksara

[4]. Indriani dan Kamaludin. (2012). Manajemen Keuangan Edisi Revisi. Bandung: CV. Mandarmaju

[5]. Jusuf, Soewadji. (2012). Pengantar Metodologi Penelitian. Jakarta: Mitra Wacana Media

[6]. Kasmir. (2012). Analisis Laporan Keuangan. Jakarta: PT. Rajagrafindo Perkasa

[7]. Misbahuddin dan Hasan, Iqbal. (2013). Analisis Data Penelitian dengan Statistik

[8]. Edisi ke-2. Jakarta: Bumi Aksara.

[9]. Nazir, Moh. (2011). Metode Penelitian. Bogor: Ghalia Indonesia

[10]. Nidar, Sulaeman (2016). Manajemen Keuangan Perusahaan Modern. Bandung: Pustaka Reka Cipta

[11]. Prastowo, Dwi (2015). Analisis Laporan Keuangan Konsep dan Aplikasi. Yogyakarta: STIM YKPN

[12]. Prihadi, Toto (2013). Analisis Laporan Keuangan Lanjutan. Jakarta: PPM

[13]. Samryn. (2012). Akuntansi Manajemen. Jakarta: Kencana

[14]. Sugiyono. (2012). Metode Penelitian Kuantitatif, Kualitatif dan R\&D. Bandung: CV. Alfabeta

[15]. ...............(2014). Metode Penelitian Kuantitatif, Kualitatif dan R\&D. Bandung:

[16]. CV. Alfabeta

[17]. Sugiono dan Untung. (2016). Panduan Praktis Analisa Laporan Keuangan. Jakarta: PT. Grasindo

[18]. Utari dkk (2014). Manajemen Keuangan. Jakarta: Mitra Wacana Media

[19]. Wahyudiono, Bambang. (2014). Mudah Membaca Laporan Keuangan. Jakarta: Raih Asa Sukses 